\title{
Genomics of adaptation and wood properties in Populus trichocarpa
}

\author{
Carl Douglas \\ From IUFRO Tree Biotechnology Conference 2011: From Genomes to Integration and Delivery \\ Arraial d'Ajuda, Bahia, Brazil. 26 June - 2 July 2011
}

Populus trichocarpa (black cottonwood) and P. balsamifera (balsam poplar) are native to North America where large natural populations exist. P. trichocarpa has an extensive north-south range along the west coast, while $P$. balsamifera has a northerly range across the continent from Alaska to the North American east coast. Both species are well suited for highly productive bioenergy biomass plantations in north-temperate climates. We are investigating the large reservoirs of natural genotypic and phenotypic variation in wild populations of these species, with an initial focus on $P$. trichocarpa, to identify allelic variation underlying optimal biofuel and biomass traits that could be used for accelerated domestication. We sampled genetic variation in P. trichocarpa by Illumina transcriptome resequencing of 20 individuals from provenances along a latitudinal gradient from 60 ? $\mathrm{N}$ to 44 ? $\mathrm{N}$. This analysis revealed extensive nucleotide, gene expression and alternative splicing polymorphism in 10,000 xylem-expressed genes. Alignment of transcript sequences to the $P$. trichocarpa Nisqually-1 reference genome was used to identify over 500,000 SNPs. These SNPs were combined with a larger SNP set generated by whole genome resequencing of multiple $P$. trichocarpa individuals carried out by the US DOE Bioenergy Sciences Center (BESC) to populate a P. trichocarpa SNP database. Using the Illumina iSelect process, we generated an Illumina Infinium bead array for genotyping of 34,000 SNPs that tag 3,700 candidate genes selected for their potential involvement in biomass, adaptation, and wood traits. Using this bead array in collaboration with BESC, we obtained candidate gene SNP genotypes for over $700 P$. trichocarpa individuals grown in common gardens. This analysis of these data revealed extensive genotypic polymorphism in the targeted gene set. In parallel, we carried out phenotyping

Correspondence: carl.douglas@ubc.ca

University of British Columbia, USA

C Biomed Central

( 2011 Douglas; licensee BioMed Central Ltd. This is an open access article distributed under the terms of the Creative Commons Attribution License (http://creativecommons.org/licenses/by/2.0), which permits unrestricted use, distribution, and reproduction in any medium, provided the original work is properly cited. of the trees from the wild populations grown in common gardens, quantifying variation in over 85 morphological, growth, physiological, wood chemistry, and wood quality traits. Population genetic analysis of the SNP data, its use for genotype-phenotype association studies to identify candidate gene alleles underlying variation in traits of interest, and the prospects of using the results for marker assisted breeding will be discussed.

Published: 13 September 2011

doi:10.1186/1753-6561-5-S7-O2

Cite this article as: Douglas: Genomics of adaptation and wood

properties in Populus trichocarpa. BMC Proceedings 2011 5(Suppl 7):O2.

Submit your next manuscript to BioMed Central and take full advantage of:

- Convenient online submission

- Thorough peer review

- No space constraints or color figure charges

- Immediate publication on acceptance

- Inclusion in PubMed, CAS, Scopus and Google Scholar

- Research which is freely available for redistribution 